DOI: 10.33766/2524-0323.92.63-74

УДК 342.95:[342.51:001.89](477)

В. С. Тарасенко, аспірантка Харківського національного університету внутрішніх справ (м. Харків, Україна) e-mail: vs.tarasenko@ukr.net (iDhttps:// orcid.org/0000-0003-0864-4161

\title{
ПОНЯТТЯ ТА ОЗНАКИ ОРГАНІВ ВИКОНАВЧОЇ ВЛАДИ У СФЕРІ НАУКОВОЇ ТА НАУКОВО-ТЕХНІЧНОЇ ДІЯЛЬНОСТІ В УКРАЇНІ
}

За результатами проведеного дослідження надано визначення поняття органів виконавчої влади у сфері наукової та науково-технічної діяльності в Україні, визначено їх місце в системі органів виконавчої влади, встановлено коло ознак органів виконавчої влади у сфері наукової та науково-технічної діяльності та надано їх класифікацію за ступенем узагальненості. Зазначено, що органи виконавчої влади у сфері наукової та науково-технічної діяльності в Україні можна визначити як різновид органів державної влади, що мають ієрархічну структуру, діяльність яких спрямована на виконання законів та інших нормативно-правових актів та полягає в підзаконному адміністративно-правовому регулюванні (адмініструванні) суспільних відносин у сфері наукової та науково-технічної діяльності в Україні.

Ключові слова: система органів виконавчої влади та їі ознаки, наукова та науковотехнічна діяльність, адміністративно-правове регулювання.

Постановка проблеми. Наукова та науково-технічна діяльність є рушійною силою економічного розвитку держави, засобом покращення якості життя людини. Також вона постає об'єктом державного регулювання та управління, що в першу чергу здійснюється через функціонування визначеного кола органів виконавчої влади. Від ефективності їх діяльності, виваженого, чіткого підходу до розподілу повноважень між ними залежить формування ефективної державної політики щодо розвитку наукової та технічної сфери в країні.

Ключову позищію в дослідженні проблем правого регулювання суспільних відносин, що виникають між органами виконавчої влади та суб'єктами наукової та науково-технічної діяльності посідає адміністративно-правова доктрина. Наукове дослідження цієї проблематики, як і буд-якої іншої, розпочинається із визначення поняття, що становить предмет дослідження, та встановлення всіх його характерних ознак.

Однак, у сучасній науці адміністративного права питання визначення поняття органів виконавчої влади у сфері наукової та науково-технічної діяльності в Україні та їх ознак майже не досліджувались. Відсутнє визначення поняття цієї категорії, рівно як і не виокремлені їі суттєві ознаки.

Аналіз останніх досліджень і публікацій. Питанню визначення поняття органів виконавчої влади в цілому та їх ознак приділяли значну увагу такі науковці, як: В. Б. Авер'янов, Л. Р. Біла-Тіунова, Т. І. Білоус-Осінь, Ю. П. Битяк, А. С. Васильєв, С. В. Ківалов, В. К. Колпаков, О. В. Кузьменко, Л. В. Коваль, О. В. Кузьменко, В. Я. Ма- 
линовський, Н. П. Матюхіна, О. І. Остапенко, І. Д. Пастух, М. В. Плугатир, М. В. Співак та ін. Проте, на сьогодні визначення особливостей поняття органів виконавчої влади у сфері наукової та науково-технічної діяльності та їх ознак залишається поза колом наукових досліджень.

Формулювання цілей. Метою дослідження постало надання визначення поняття органів виконавчої влади у сфері наукової і науково-технічної діяльності в України та їх характерних ознак. Мета дослідження досягається шляхом вирішення наступних наукових завдань: 1) визначення існуючих у науковій літературі підходів до розуміння органів виконавчої влади в цілому; 2) їх аналіз та виокремлення суттєвих ознак цього поняття; 3) встановлення співвідношення понять органів виконавчої влади та органів виконавчої влади у сфері наукової та науковотехнічної діяльності; 4) базуючись на цьому співвідношенні, визначення досліджуваного поняття (органів виконавчої влади у сфері наукової та науково-технічної діяльності); 5) надання класифікації ознак органів виконавчої влади у сфері наукової та науково-технічної діяльності.

Виклад основного матеріалу. Адміністративно-правовій доктрині відомі диференщійовані підходи до визначення поняття «органи виконавчої влади», у яких відображено різні суттєві ознаки цієї категорії. Наприклад, А. С. Васильєв під органом державної виконавчої влади розуміє первинний елемент апарату державного управління, який утворюється державою для здійснення від ії імені завдань і функцій державної виконавчої влади [1, с. 78]. Науковець виділяє три суттєві ознаки органу виконавчої влади: 1) він є первинним елементом апарату державного управління, 2) утворюється державою та 3) здійснює від імені держави завдання і функції державної виконавчої влади.

В. К. Колпаков та О. В. Кузьменко визначають це поняття як носія державної виконавчої влади, що реалізує свою компетенщію в закріпленій сфері державного управління і має юридичний (нормативно-зафіксований) статус органу державної виконавчої влади [2, с. 92]. На думку науковців, органи виконавчою влади також мають три суттєві ознаки: 1) вони є носіями державної виконавчої влади, 2) реалізують свою компетенцію в закріпленій сфері державного управління та 3) мають юридичний статус органу державної виконавчої влади.

Аналогічне визначення надають С. В. Ківалов, Л. Р. Біла-Тіунова та Т. І. Білоус-Осінь, за винятком того, що науковці застосовують поняття «публічне адміністрування», замість «державне управління» [3, с. 31].

На думку В. Я. Малиновського, органи виконавчої влади є різновидом органів державної влади в цілому, які, відповідно до конституційного принщипу поділу влади, призначені реалізовувати функції, покладені на виконавчу гілку влади та мають для цього відповідну компетенцією [4, с. 77]. Отже, науковець також виділяє три ознаки органів виконавчої влади: 1) вони є різновидом органів державної влади; 2) призначені реалізовувати функції, покладені на виконавчу гілку влади та 3) мають для цього відповідну компетенцією.

Л. В. Коваль стверджує, що під поняттям «орган виконавчої влади» слід розуміти організащійно відокремлену частину державно-управлінського апарату, що здійснює від імені і за дорученням держави відповідні функщії, i, унаслідок цього, 
він наділений відповідною компетенцією, певною організаційною структурою, територіальним масштабом діяльності [5, с. 32].

Така ознака, як здійснення від імені держави завдань і функцій державної виконавчої влади, запропонована А. С. Васильєвим, є наближеною до ознаки, запропонованої В. К. Колпаковим та О. В. Кузьменко, котрі зазначають, що органи виконавчої влади є носіями державної виконавчої влади, а також до ознаки, запропонованої В. Я. Малиновським, відповідно до якої органи виконавчої влади призначені реалізовувати функції, покладені на виконавчу гілку влади. Цілком зрозуміло, якщо орган виконавчої влади є носієм державної виконавчої влади (що не викликає заперечень), та, відповідно, здійснює завдання і функції державної виконавчої влади й має юридичний статус органу державної виконавчої влади.

Щодо останньої ознаки, запропонованої В. К. Колпаковим та О. В. Кузьменко, то слід наголосити, що вона (ознака) має значення, адже прямо вказує на приналежність органів виконавчої влади до системи органів державної влади. Відомо, що виконавчі органи влади можуть мати місце і у сфері місцевого самоврядування і навіть у приватній сфері (наприклад, виконавчий комітет місцевої ради чи виконавчий директор приватного підприємства). Аналогічну ознаку виділяє і В. Я. Малиновський, який прямо вказує на те, що органи виконавчої влади є різновидом органів державної влади.

Іншою спільною ознакою органів виконавчої влади, яку виділяють такі науковці, як: В. К. Колпаков, О. В. Кузьменко, В. Я. Малиновський та Л. В. Коваль, є наявність власної компетенції. Причому, перші двоє дослідників зазначають, що така компетенція має місце в закріпленій сфері державного управління, 3 чого слід розуміти, що кожен орган виконавчої влади функціонує щодо певної сфери суспільного життя.

Запропонована А. С. Васильєвим ознака про те, що кожен орган виконавчої влади є первинним елементом апарату державного управління, $є$ аналогічною із запропонованою ознакою Л. В. Коваль, яка стверджує, що орган виконавчої влади $є$ організаційно відокремленою частиною державно-управлінського апарату. Фактично обидва науковці вказують на приналежність органів виконавчої влади до апарату державного управління, хоча і застосовують при цьому дещо різні формулювання. Як відомо, під апаратом державного управління розуміється вся сукупність органів виконавчої влади та їх структурних підрозділів.

Ознака, надана А. С. Васильєвим, яка вказує на те, що органи виконавчої влади створюються державою в цілому, є справедливою, проте вона випливає із відомого факту, що органи виконавчої влади є різновидом органів державної влади. Органи державної влади створюються саме державою, а не будь-якою іншою формою організації суспільства.

Н. П. Матюхіна орган виконавчої влади визначає як частину державного апарату (організацію), яка має власну структуру та штат службовців, територіальний масштаб діяльності, утворюється в установленому законом або іншими правовими актами порядку і в межах передбаченої компетенції здійснює від імені і за дорученням держави функції державного управління в економічній, соціальнокультурній, адміністративно-політичній сферах суспільного життя [6, с. 75]. 
O. I. Остапенко надає аналогічне визначення цього поняття, окрім того, що воно не містить вказівки на територіальний характер діяльності органів виконавчої влади [7, с. 151].

Схожим є визначення, відповідно до якого органи виконавчої влади розглядаються як частина державного апарату, що має власну структуру та штат службовців і в межах установленої компетенщії здійснюють на основі законів та з їх виконання, від свого імені й за дорученням народу України підзаконне адміністративно-правове регулювання (адміністрування) в галузях, сферах і секторах суспільних відносин [8, с. 92]. Автори цього визначення, на відміну від попередніх двох, наголошують на здійсненні органами виконавчої влади діяльності на основі законів та їх виконання.

І якщо перша з названих ознак не є специфічною для органів виконавчої влади, адже стосується абсолютно всіх органів державної влади, з огляду на адміністративно-правовий принцип законності, що відображений у ч.2 ст. 19 Конституції України, то друга ознака дозволяє виокремити органи виконавчої влади серед комплексу інших органів державної влади, оскільки не всі органи державної влади у своїй діяльності спрямовані на виконання законів. Це конституційна функція саме органів виконавчої влади.

На думку науковців О. В. Кузьменко, І. Д. Пастуха, М. В. Плугатира та М.В.Співака, орган виконавчої влади є організаційно самостійним елементом державного апарату (механізму держави), який наділений чітко окресленим обсягом повноважень (компетенщією), відповідно до покладених на нього завдань і функцій, складається із структурних підрозділів і посад, що обіймають державну службовці, і віднесений Конституцією і законами України до системи органів виконавчої влади [9, с. 36]. Указані науковці, на відміну від зазначених раніше, вказують на приналежність органів виконавчої влади до державного апарату, що є дещо відмінним від поняття апарату державного управління. Ці категорії слід розглядати як ціле та частина. Так у літературі прийнятним є судження, коли державний апарат визначають як сукупність усіх державних органів [10, с. 565; 11, с. 11; 12, с. 57].

На відміну від державного апарату, поняття апарату державного управління містить сукупність не всіх органів державної влади, а лише ії виконавчої гілки. Отже, запропонована вченими ознака не є родовою ознакою органів виконавчої влади, а є загальною для всіх органів державної влади без винятку, через те ії застосування у визначенні поняття органів виконавчої влади є спірним.

Такі ознаки, як наявність чітко окресленого обсягу повноважень, завдань і функцій, структурних підрозділів і посад, приналежність до системи органів виконавчої влади наголошувались у тій чи іншій інтерпретації й іншими науковцями.

Загальний аналіз запропонованих у літературі дефініцій поняття «органи виконавчої влади» вказує на різноманітність підходів до його визначення. Основним недоліком деяких із них вбачається відсутність акцентів на суттєві родові ознаки цього поняття. Багато ознак, через які визначають те поняття, є загальними та характеризують органи державної влади в цілому. 
Наприклад, вказівка на те, що органи виконавчої влади створюються державою та від їі імені здійснюють свою діяльність, стосується й державних органів законодавчої і судової гілок влади. Аналогічно це стосується таких ознак, як: наявність власної структури та штату службовців, територіального масштабу діяльності чи здійснення ними своєї компетенції на основі законів.

Будь-який державний орган має власну структуру, штат службовців, його діяльність масштабується на всю територію держави або певного ії регіону (адміністративно-територіальної одиниці). Іншими словами, ці ознаки є похідними від ознаки «органи державної влади» та видовими для всіх органів державної влади. На нашу думку, вони призводять до зайвого навантаження поняття та можуть бути враховані шляхом включення до складу визначення органу виконавчої влади вказівки, що вони $є$ різновидом органів державної влади в цілому.

Отже, важливою ознакою органів виконавчої влади є їх дотичність та зв' язок з органами державної влади в цілому. Як їх складова частина, органи виконавчої влади мають усі найважливіші ознаки державних органів: виконують значний обсяг завдань і функцій держави, виступають від імені держави, наділені державними владними повноваженнями.

Водночас органи виконавчої влади мають і власні специфічні риси, обумовлені призначенням, змістом їх діяльності, iї особливим характером. Саме на ці ознаки слід робити акцент під час визначення їх поняття.

Перша i, мабуть, найголовніша закріплена в ст. 6 Конституцій України, де зазначено, що державна влада в Україні здійснюється на засадах їі поділу на законодавчу, виконавчу та судову. Отже, ознакою, за допомогою якої органи виконавчої влади можливо вирізнити із системи органів державної влади - це виконавчий характер їх діяльності, яка спрямована на розроблення і втілення державної політики щодо забезпечення виконання законів та управління сферами суспільного життя шляхом видання підзаконних актів і виконання організаційних дій.

Другою специфічною ознакою органів виконавчої влади є не просто наявність власної структури, а їі особливість, яка носить строго ієрархічний характер, де нижчі органи виконавчої влади перебувають у прямому підпорядкуванні та контролюються вищими. Наприклад, Міністерство юстищії - у підпорядкуванні Кабінету Міністрів України. Міністерству, своєю чергою, підпорядковуються територіальні управління юстиції в областях.

Обласні державні адміністрації також перебувають у підпорядкуванні Кабінету Міністрів України, а їм, відповідно, підпорядковані районні державні адміністрації. Це ж стосується й тих центральних органів виконавчої влади, що не утворюють власної підсистеми. Наприклад, Національне агентство 3 питань запобігання корупщії, згідно зі ст. 4 Закону України «Про запобігання корупщії, є підзвітним Кабінету Міністрів України.

На відміну від органів виконавчої влади, ані законодавчий орган (Верховна Рада України), ані органи судової влади не характеризуються такою ознакою. Верховна рада України, відповідно до ст. 75 Конституції України, реалізує законода- 
вчу владу одноособово, тому і про існування ієрархічної структури в рамках законодавчої влади в Україні мова йти не може, адже для створення ієрархічної структури необхідно принаймні два елементи.

Щодо органів судової влади, то про існування в цій підсистемі органів державної влади ієрархії мова йти також не може, адже ця структура, відповідно до ст. 1 Закону України «Про судоустрій і статус суддів», складається з незалежних один від одного елементів - судів. Незалежність є ознакою-антиподом до ознаки ієрархічності, адже вона виключає підпорядкування та контроль з боку інших елементів структури. Наприклад, місцеві суди не перебувають у прямому підпорядкуванні апеляційних судів або Верховного Суду.

Підсумовуючи викладене, пропонуємо наступне визначення органів виконавчої влади: це різновид органів державної влади, що мають ієрархічну структуру, діяльність яких спрямована на виконання законів та інших нормативно-правових актів та полягає в підзаконному адміністративно-правовому регулюванні (адмініструванні) в економічній, соціально-культурній та адміністративно-політичній сферах суспільних відносин.

У частині адміністрування сфер суспільних відносин не залишається осторонь і сфера наукової та науково-технічної діяльності в Україні, яка структурно входить до складової частини соціально-культурної сфери [6, с. 412, 423].

Через те органи виконавчої влади у сфері наукової та науково-технічної діяльності в Україні можна визначити як різновид органів державної влади, що мають ієрархічну структуру, діяльність яких спрямована на виконання законів та інших нормативно-правових актів та полягає в підзаконному адміністративно-правовому регулюванні (адмініструванні) суспільних відносин у сфері наукової та науково-технічної діяльності в Україні.

У науці окремо виділяють ознаки органів виконавчої влади, більшість з яких у дефініції цього поняття не відбито. Найбільш суттєвими ознаками органів виконавчої влади на сьогодні визнають таке.

1. Кожен орган виконавчої влади, діючи від імені та за дорученням держави, має певний правовий статус, виступає носієм відповідних державно-владних повноважень, які використовуються ним виключно з метою державно-управлінської діяльності.

2. Основним змістом діяльності органів виконавчої влади є здійснення державного управління в соціально-економічній та інших сферах життя суспільства.

3. Створення, структура, порядок діяльності і компетенція органів виконавчої влади визначаються Конституцією та законами України, актами Президента України та іншими нормативно-правовими актами.

4. Органи виконавчої влади діють на вищому (Кабінет Міністрів України), центральному (центральні органи виконавчої влади) та на регіональному (місцеві органи виконавчої влади) рівнях і створюють єдину систему.

5. У межах цієї системи органи виконавчої влади наділяються необхідною оперативною самостійністю, що виражається в їх компетенщії - предметах відання, правах, обов' язках, територіальних межах діяльності кожного окремого органу. 
6. Діяльність органів виконавчої влади має підзаконний, виконавчо-розпорядчий характер, вони здійснюють свої функції на підставі та на виконання закону.

7. Реалізуючи свою компетенщію, виконуючи положення законів та правових актів інших державних органів, органи виконавчої влади мають повноваження розпоряджатися з конкретних питань та приймати підзаконні нормативні акти. У процесі виконавчої та розпорядчої діяльності вони діють юридично-владно, застосовуючи різні правові засоби нормотворчого, виконавчого (розпорядчого) та юрисдикційного (правоохоронного) характеру.

8. Кожен орган виконавчої влади має визначений для нього законодавством територіальний масштаб діяльності, який враховує особливості адміністративнотериторіального устрою України.

9. Органи виконавчої влади мають власну внутрішню структуру, штат державних службовців, який сформований шляхом їх конкурсного відбору або призначення на посаду для здійснення конкретної виконавчо-розпорядчої діяльності в юридично-владній формі. У межах кожного органу поміж структурними підрозділами і службовцями розподілені повноваження і відповідальність за доручену справу, встановлені та розвиваються різні організаційно-правові зв' язки.

10. Кожен орган виконавчої влади має офіційне найменування та повноваження використовувати різні атрибути з державною символікою.

11. Фінансування органів виконавчої влади здійснюється із державного бюджету [6, с. 75-77].

Можна переконатися, що не всі з перелічених ознак віддзеркалюють особливості виключно органів виконавчої влади. Чимало 3 них стосуються органів державної влади в цілому. Тому за ступенем узагальненості їх можливо розподілити на загальні та родові. Загальні - це ті, які віддзеркалюють особливості органів державної влади та, відповідно, й органі виконавчої влади як частини цієї загальної системи. Вони характеризують, поряд із органами виконавчої гілки влади, й особливості органів законодавчої та судової гілок влади.

Родові ознаки відображають особливості виключно органів виконавчої влади, що формують власну підсистему органів державної влади.

Ба більше, цілком можливо вести мову про існування видових та безпосередніх ознак органів виконавчої влади. Ці ознаки характеризують не всі органи виконавчої влади, а окремі групи або окремі органи. Зокрема, на підставі видових о3нак здійснюється класифікація органів виконавчої влади на органи загальної та спеціальної компетенції, за сферами публічного управління (адміністрування) тощо. Безпосередні ознаки дозволяють виокремити конкретний орган серед певного виду. Наприклад, такою ознакою є особливості найменування органу виконавчої влади, який здійснює публічне управління (адміністрування) у визначеній сфері. Через існування видових і безпосередніх цих ознак, власне, і постає можливим виокремлення певного органу серед усього загалу органів виконавчої влади, що існують в Україні.

На підставі зазначеного можливо визначити загальні, родові, видові та безпосередні ознаки органів виконавчої влади у сфері наукової та науково-технічної діяльності в Україні. Перша із наведених у літературі сукупність ознак є загальною, 
адже не тільки органи виконавчої гілки влади діють від імені та за дорученням держави, мають певний правовий статус, виступають носієм відповідних державно-владних повноважень.

Ці властивості цілком притаманні й органам законодавчої та судової гілок влади. Родовою тут є ознака, що характеризує мету перелічених властивостей: вони використовуються органами виконавчої влади виключно з метою державноуправлінської діяльності.

Друга ознака, яка полягає в здійсненні державного управління в соціальноекономічній та інших сферах життя суспільства є, безумовно, родовою, адже ця функція є виключною прерогативою органів виконавчої влади.

Третя ознака є загальною, адже Конституцією, законами України, актами Президента України та іншими нормативно-правовими актами визначається створення, структура, порядок діяльності і компетенщія всіх органів державної влади. Наприклад, такими підзаконними нормативно-правовими актами, як Положення про порядок роботи у Верховній Раді України із проектами законів, постанов, інших актів Верховної Ради України та Положення про помічника-консультанта народного депутата України регулюється порядок діяльності законодавчого органу влади у відповідній частині $[13,14]^{1}$.

Щодо нормативно-правого регулювання діяльності органів судової влади, то, окрім Конституції України та ряду законів, джерелом їх нормативно-правового регулювання виступають й підзаконні акти, наприклад, Указ Президента України «Про ліквідацію апеляційних господарських судів та утворення апеляційних господарських судів в апеляційних округах» від 29.12.2017 № 454/2017 [15]² або ж Правила поведінки працівника суду, затверджених рішенням Ради суддів України від 06 лютого 2009 року № 33 [16]³ .

Четверта ознака є родовою, адже характеризує особливості вертикальної системи власне органів виконавчої влади, оскільки лише останні діють одночасно на вищому, центральному та регіональному рівнях.

П'ята ознака є загальною, адже буд-який орган державної влади наділений оперативною самостійністю, має свою компетенцію - предмет відання, права, обов' язки, територіальні межі діяльності.

Шосту ознаку слід визнати родовою, тому що діяльність лише органів виконавчої влади має виконавчо-розпорядчий характер, лише вони здійснюють свої функції на виконання закону.

\footnotetext{
1 Про затвердження Положення про порядок роботи у Верховній Раді Украӥни із проектами законів, постанов, інших актів Верховної Ради Украӥни: Розпорядження Голови Верховної Ради Украӥни від 22.05.2020 № 428. URL : https://zakon.rada.gov.ua/laws/show/428/06-\%D1\%80\%D0 \%B3\#Text; Про затвердження Положення про помічника-консультанта народного депутата України: Постанова Верховної Ради України. Відомості Верховної Ради України (ВВР), 1995, № 37, ст. 283.

${ }^{2}$ Про ліквідацію апеляційних господарських судів та утворення апеляційних господарських судів в апеляційних округах: Указ Президента Украӥни від 29.12.2017 № 454/2017. URL : https:/ zakon. rada.gov. ua/laws/show/454/ 2017\#Tехt. (дата звернення: 04.12.2020)

3 Правила поведінки працівника суду: рішення Ради суддів від 06.02.2009 № 72. URL : http://rsu.gov. ua/ua/ documents/101. (дата звернення: 04.12.2020)
} 
Сьома ознака є загальною, адже не лише органи виконавчої влади мають повноваження розпоряджатися з конкретних питань та приймати підзаконні нормативні акти. Не тільки вони діють юридично-владно, застосовуючи різні правові засоби нормотворчого, розпорядчого та юрисдикційного характеру.

Восьма ознака також є загальною; кожен орган державної влади має визначений для нього законодавством територіальний масштаб діяльності, який враховує особливості адміністративно-територіального устрою України.

Дев'ята ознака має загальний характер. Усі без винятку органи державної влади мають власну внутрішню структуру, штат державних службовців, який сформований шляхом їх конкурсного відбору або призначення на посаду. Застосовується принцип розподілу повноважень і відповідальності

Останні дві ознаки також загальні. Наявність офіційного найменування, повноваження використовувати різні атрибути з державною символікою та фінансування із державного бюджету є ознакою органів державної влади в цілому.

Видові ж ознаки органів виконавчої влади, зокрема і тих, що здійснюють державне управління (адміністрування) у сфері наукової і науково-технічної діяльності, залежать від таких критеріїв, як: особливості територіального масштабу діяльності, обсягу і характеру компетенщії, порядку розв' язання підвідомчих питань та інших [6, с. 77-80]. Наприклад, за таким критерієм, як: предмет спрямованості компетенції, видовою ознакою органів виконавчої влади у сфері наукової та науковотехнічної діяльності, є здійснення ними управління сферою науки і техніки.

Безпосередніми ознаками окремих органів виконавчої влади у сфері наукової і науково-технічної діяльності є: власне найменування, місцезнаходження, особливості внутрішньої структури, порядок розв' язання підвідомчих питань тощо. Щодо останньої ознаки, то слід зазначити, що серед органів виконавчої влади у сфері наукової та науково-технічної діяльності колегіальним є лише Кабінет Міністрів України.

Висновки. У результаті проведеного наукового дослідження встановлено, що органи виконавчої влади у сфері наукової та науково-технічної діяльності слід розуміти як різновид органів державної влади, що мають ієрархічну структуру, діяльність яких спрямована на виконання законів та інших нормативно-правових актів та полягає в підзаконному адміністративно-правовому регулюванні (адмініструванні) суспільних відносин у сфері наукової та науково-технічної діяльності в Україні.

Класифікацію ознак органів виконавчої влади у сфері наукової та науковотехнічної діяльності в Україні слід здійснювати за ступенем узагальненості, як-от: загальні - ті, що притаманні всім органам державної влади; родові - ті, що розкривають особливості органів виконавчої влади в цілому; видовi - стосуються органів виконавчої влади певного виду; та безпосередні - розкривають специфічні риси конкретного органу виконавчої влади.

\section{Використані джерела}

1. Васиљьев А. С. Административное право Украины. Харьков : Одисей, 2001. 143 с.

2. Колпаков В., Кузьменко О. Адміністративне право України : підручник. Київ, 2003. 544 c. 
3. Ківалов С. В. Адміністративне право: навчально-методичний посібник (для здобувачів вищої освіти денної форми навчання) / С. В. Ківалов, Л. Р. Біла-Тіунов, Т. І. Білоус-Осінь. Одеса : Фенікс, 2019. 136 с.

4. Малиновський В. Я. Державне управління: навч. посібник. Луцьк : Ред.-вид. від. «Вежа» Вол. держ. ун-ту ім. Лесі Українки, 2000. 558 с.

5. Коваль Л. В. Адміністративне право: гурс лекцій для студентів юрид. вузів та факультетів. Київ : Вентурі., 1998. 208 с.

6. Битяк Ю. П. Адміністративне право України: підручник / Ю. П. Битяк, В. М. Гаращук, В. В. Богуцький та ін. ; за заг. ред. Ю. П. Битяка, В. М. Гаращука, В. В. Зуй. 2-ге вид., перероб та доп. Харків : Право, 2013. 656 с.

7. Остапенко О. І. Адміністративне право: навч. посіб. / О. І. Остапенко, 3. Р. Кісіль, М. В. Ковалів та ін. 2-ге вид. Київ: Алеута : КТН; ЦКЛ, 2009. 536 с.

8. Адміністративне право України. Повний курс : підручник / Галунько В., Діхтієвський П., Кузьменко О., Стеценко С. та ін. Херсон : ОЛДІ-ПЛЮС, 2018. 446 с.

9. Адміністративне право. Загальна частина (альбом схем) : навч. посіб. / О. В. Кузьменко, І. Д. Пастух, М. В. Плугатир, М. В. Співак. Київ : «Центр учбової літератури», 2015. 232 c.

10. Проблемы общей теории права и государства ; под ред. В. С. Нерсесянща. Москва : Норма, 2004. 832 с.

11. Загальна теорія держави і права ; за ред. М. В. Цвіка, В. Д. Ткаченка, О. В. Петришина. Харків : Право, 2002. С. 11

12. Адміністративне право України : підручник у 2 т. Т. 1: Загальна частина / В. Б. Авер'янов. Київ : Юрид. думка, 2004. С. 57.

13. Про затвердження Положення про порядок роботи у Верховній Раді України із проектами законів, постанов, інших актів Верховної Ради України: Розпорядження Голови Верховної Ради України від 22.05.2020 № 428. URL : https:/ /zakon. rada.gov.ua/laws/ show $/ 428 / 06-\%$ D1\%80\%D0\%B3\#Text. (дата зверне ння: 04.12.2020)

14. Про затвердження Положення про помічника-консультанта народного депутата України: Постанова Верховної Ради України. Відомості Верховної Ради України (ВВР), 1995, № 37, ст. 283.

15. Про ліквідацію апеляційних господарських судів та утворення апеляційних господарських судів в апеляпійних округах: Указ Президента України від 29.12.2017 № 454/ 2017. URL : https:/ / zakon.rada.gov.ua/laws/show/454/2017\#Text. (дата звернення: 04.12. 2020)

16. Правила поведінки працівника суду: рішення Ради суддів від 06.02.2009 № 72. URL : http://rsu.gov.ua/ua/documents/101. (дата звернення: 04.12.2020)

\section{References:}

1. Vasylev, A. S. (2001) Admynystratyvnoe pravo Ukrayny. Kharkiv : Odysei. [in Ukrainian].

2. Kolpakov, V., Kuzmenko, O. (2003) Admynystratyvnoe pravo Ukrayny : pidruchnyk. Kyiv. [in Ukrainian].

3. Kivalov, S. V., (2019). Administratyvne pravo: navchalno-metodychnyi posibnyk (dlia zdobuvachiv vyshchoi osvity dennoi formy navchannia). S. V. Kivalov, L. R. Bila-Tiunov, T. I. Bilous-Osin (Eds.). Odesa : Feniks.[in Ukrainian].

4. Malinovskiy, V. Ya. (2000). Derzhavne upravlinnia : pidruchnyk. Lutsk : Vezha. [in Ukrainian].

5. Koval, L. V. (1998). Administratyvne pravo: kurs lektsii dlia studentiv yuryd. vuziv ta fakultetiv. Kyiv : Venturi. [in Ukrainian]. 
6. Bytiak, Yu. P. (2013). Administratyvne pravo Ukrainy : pidruchnyk. V. V. Bogutsky, Yu. P. Bytyak, V. M. Garashchuk (Eds.) et al; Yu. P. Bityak (Ed.), \& , V. M. Garashchuk, V. V. Zui,. Kharkiv : Pravo. [in Ukrainian].

7. Ostapenko O. I. (2009) Administratyvne parvo : navch. posib. O. I. Ostapenko, Z. R. Kisil, M. V. Kovaliv. (Eds.) et al. Kyiv : Aleuta: KTN; CCL. [in Ukrainian].

8. Administratyvne pravo Ukrainy. Povnyi kurs : pidruchnyk (2018). Galunko V., Dikhtievsky P., Kuzmenko O., Stetsenko S. (Eds.) et al. Kherson : OLDI-PLUS. in Ukrainian].

9. Administratyvne pravo. Zahalna chastyna (albom skhem): navch. posib. (2015). O. V. Kuzmenko, I. D. Pastukh, M. V. Plugatyr, M. V. Spivak (Eds.). Kyiv : Center for Educational Literature. [in Ukrainian].

10. Problemy obshchei teoryy prava y gosudarstva (2004). V. S. Nersesyants (Ed.). Moskva : Norma. [in Ukrainian].

11. Zahalna teoriia derzhavy i prava (2009). M. V. Tsvik, V. D. Tkachenko, O. V. Petrishin (Eds). Kharkiv : Pravo. [in Ukrainian].

12. Administratyvne parvo : pidruchnyk. Zahalna chastyna (2004) (Vol 1-2; Vol. 1) V. B. Averyanov. Kyiv : Yuryd. dumka. [in Ukrainian].

13. Pro zatverdzhennia Polozhennia pro poriadok roboty u Verkhovnii Radi Ukrainy iz proektamy zakoniv, postanov, inshykh aktiv Verkhovnoi Rady Ukrainy: Rozporiadzhennia Holovy Verkhovnoi Rady Ukrainy vid 22.05.2020 № 428. (2020) N. p. URL : https://zakon.rada.gov.ua/laws/show/428/06-\%D1\%80\%D0\%B3\#Text. [In Ukranian].

14. Pro zatverdzhennia Polozhennia pro pomichnyka-konsultanta narodnoho deputata Ukrainy: Postanova Verkhovnoi Rady Ukrainy. (1995) Vidomosti Verkhovnoi Rady Ukrainy (VVR)- Information of the Verkhorna Rada of Ukraine (VVR), 37, art. 283. [In Ukranian].

15. Pro likvidatsiiu apeliatsiinykh hospodarskykh sudiv ta utvorennia apeliatsiinykh hospodarskykh sudiv v apeliatsiinykh okruhakh: Ukaz Prezydenta Ukrainy vid 29.12.2017 № 454/2017. (2017) N. p. URL: https:/ /zakon.rada.gov.ua/laws/show/454/2017\#Text. [in Ukranian].

16. Pravyla povedinky pratsivnyka sudu: rishennia Rady suddiv vid 06.02.2009 № 72 . (2009) N. p. URL: http:/ /rsu.gov.ua/ ua/documents/101. [in Ukranian].

Стаття надіӥшла до редколегіï 04.12.2020

Тарасенко В. C., аспирантка Харьковского национального университета внутренних дел (г. Харьков, Украина)

\section{ПОНЯТИЕ И ПРИЗНАКИ ОРГАНОВ ИСПОЛНИТЕЛЬНОЙ ВЛАСТИ В СФЕРЕ НАУЧНОЙ И НАУЧНО-ТЕХНИЧЕСКОЙ ДЕЯТЕЛЬНОСТИ В УКРАИНЕ}

В статье дано определение понятия органов исполнительной власти в сфере научной и научно-технической деятельности в Украине, определено их место в системе органов исполнительной власти, установлен круг признаков органов исполнительной власти в сфере научной и научно-технической деятельности и предоставлены их классификацию по степени обобщенности.

Указано, что органы исполнительной власти в сфере научной и научно-технической деятельности в Украине можно определить как разновидность органов государственной власти, имеющих иерархическую структуру, деятельность которых 
направлена на выполнение законов и других нормативно-правовых актов и заключается в подзаконном административно-правовом регулировании (администрировании) общественных отношений в сфере научной и научно-технической деятельности в Украине.

Ключевые слова: система органов исполнительной власти, понятие об органах исполнительной власти, административно-правовое регулирование.

\author{
Tarasenko V., \\ Graduate Student of Kharkov National \\ University of Internal Affairs \\ (Kharkiv, Ukraine)
}

\title{
CONCEPT AND SIGNS OF EXECUTIVE AUTHORITIES IN THE FIELD OF SCIENTIFIC AND SCIENTIFIC AND TECHNICAL ACTIVITY IN UKRAINE
}

According to the results of the study, the concept of executive bodies in the field of scientific and scientific-technical activities in Ukraine is defined, their place in the system of executive bodies is determined, the range of features of executive bodies in the field of scientific and scientific-technical activities is established. generalization. As a result of the conducted scientific research, it was established that the organization of the government in the sphere of science and science and technology was established as a type of agency in the government, which may be the normative structure of the government. legal regulation (administrative) of suspicious changes in the sphere of science and science and technology in Ukraine.

It is noted that the executive authorities in the field of scientific and scientific-technical activities in Ukraine can be defined as a kind of public authorities with a hierarchical structure, whose activities are aimed at implementing laws and other regulations and is by-law administrative regulation (administration) of public relations in the field of scientific and scientific and technical activities in Ukraine. In terms of administration of public relations, the sphere of scientific and scientific-technical activity in Ukraine is structurally included as an integral part of the socio-cultural sphere. The executive authorities in the field of scientific and scientific-technical activities in Ukraine form their own subsystem.

Keywords: system of executive bodies, concept and signs of executive bodies, public administration, scientific and scientific and technical activity, administrative and legal regulation. 